\title{
Binding of transition metals to S100 proteins
}

\author{
Benjamin A. Gilston ${ }^{1}$, Eric P. Skaar ${ }^{2} \&$ Walter J. Chazin ${ }^{1 *}$ \\ ${ }^{1}$ Departments of Biochemistry and Chemistry, and Center for Structural Biology, Vanderbilt University, Nashville TN 37232-9717, USA; \\ ${ }^{2}$ Department of Pathology, Microbiology and Immunology, Vanderbilt University Medical Center, Nashville TN 37232-2561, USA
}

Received March 6, 2016; accepted May 2, 2016; published online July 15, 2016

\begin{abstract}
The S100 proteins are a unique class of EF-hand $\mathrm{Ca}^{2+}$ binding proteins distributed in a cell-specific, tissue-specific, and cell cycle-specific manner in humans and other vertebrates. These proteins are distinguished by their distinctive homodimeric structure, both intracellular and extracellular functions, and the ability to bind transition metals at the dimer interface. Here we summarize current knowledge of $\mathrm{S} 100$ protein binding of $\mathrm{Zn}^{2+}, \mathrm{Cu}^{2+}$ and $\mathrm{Mn}^{2+}$ ions, focusing on binding affinities, conformational changes that arise from metal binding, and the roles of transition metal binding in S100 protein function.
\end{abstract}

S100 Proteins, Zinc, Manganese, Copper

Citation: Gilston, B.A., Skaar, E.P., and Chazin, W.J. (2016). Binding of transition metals to S100 proteins. Sci China Life Sci 59, 792-801. doi: 10.1007/s11427-016-5088-4

\section{INTRODUCTION}

S100 proteins are an important class of EF-hand calcium binding proteins distinguished by unique dimeric structures and functions both inside and outside cells (Donato, 2003; Donato et al., 2013; Nelson and Chazin, 1998; Potts et al., 1995; Zackular et al., 2015). Their intracellular functions are primarily regulatory in nature, mediated by interactions with target proteins involved in a range of processes including proliferation, differentiation, and inflammation. S100 proteins are also released or secreted from cells, where they activate a variety of cell surface receptors in both an autocrine and a paracrine manner. Several S100 proteins serve as damage-associated molecular pattern recognition factors (DAMPS) in the adaptive and innate immune systems (Donato et al., 2013), and are known to be recruited to sites of inflammation (Striz and Trebichavsky, 2004). The S100A8/S100A9 heterodimer (termed calprotectin or CP) is the most-well studied of the S100 proteins in the immune response; it has been shown to function in the response to a

*Corresponding author (email: walter.chazin@ vanderbilt.edu) range of microbial pathogens via a mechanism termed "nutritional immunity", inhibiting growth by sequestering nutrient transition metals $\mathrm{Zn}^{2+}$ and $\mathrm{Mn}^{2+}$ (Zackular et al., 2015). The binding of transition metals by S100 proteins was first characterized over 30 years ago (Baudier et al., 1982, 1984). With a specific functional role for transition metal binding by S100 proteins now emerging, it is an appropriate time to review the field. In this monograph, we will focus on the wide range of affinities for these ions, the structural consequences of transition metal binding, and how transition metal binding modulates function.

S100 proteins were first identified over five decades ago from bovine brain and are named on the basis of their solubility in $100 \%$ ammonium sulfate (Moore, 1965). To date, there are 25 members in the human proteome and homologues have only been identified only in vertebrates, suggesting that they are "evolutionary newcomers" (Schaub and Heizmann, 2008). Unlike other EF-hand proteins, they exhibit cell-type, tissue-specific, and cell cycle-dependent expression along with differential gene regulation (Schäfer and Heizmann, 1996). S100 proteins are involved in a wide range of cellular functions including intracellular calcium 
buffering, modulation of enzyme activities, energy metabolism, and regulation of cell growth, cytoskeleton development and differentiation (Schaub and Heizmann, 2008). While EF-hand proteins appear to have evolved to transduce intracellular $\mathrm{Ca}^{2+}$ signals, $\mathrm{S} 100$ proteins have the unique ability to also function in the extracellular milieu. Some S100 proteins play essential roles in signaling and secretion of ligands for receptor binding (Donato et al., 2013), modulated in certain cases by post-translational modifications and transition metal binding (Moroz et al., 2009a; van Dieck et al., 2009). S100 proteins are also part of the innate immune response to bacterial pathogens (Zackular et al., 2015). In the clinic S100 proteins serve as biomarkers for cardiomyopathy (S100A1), psoriasis (S100A7), chronic inflammation disorders and inflammatory bowel disease (S100A8/A9), and several cancers (S100A2/A4/A6) (Heizmann et al., 2002; Schäfer and Heizmann, 1996).

\section{S100 PROTEIN STRUCTURE AND BIOCHEMISTRY}

The fundamental organization for all EF-hand $\mathrm{Ca}^{2+}$ binding proteins is a four-helix bundle domain containing a pair of helix-loop-helix EF-hand motifs (Figure 1). S100 proteins, the largest subgroup within the EF-hand superfamily, are comprised of an S100-specific N-terminal EF-hand with a 14-residue $\mathrm{Ca}^{2+}$ binding loop, and a C-terminal EF-hand with a canonical 12-residue $\mathrm{Ca}^{2+}$ binding loop (Bunick et al., 2004). They are also distinguished from other EF-hand proteins (e.g. calmodulin) by obligate formation of dimers (Figure 1) (Potts et al., 1996); all function as dimers or higher order oligomers except for calbindin $\mathrm{D}_{9 \mathrm{k}}(\mathrm{S} 100 \mathrm{G})$, which is a shortened, ancestral member of the sub-family that lacks the ability to dimerize. Higher order oligomerization of S100 proteins is non-covalent and can be promoted by low affinity metal binding sites at the exterior surface of the dimer. Both $\mathrm{Ca}^{2+}$ and transition metals (particularly $\mathrm{Zn}^{2+}$ ) have been shown to stimulate oligomerization in vitro, and crystal structures have revealed a range of oligomeric states. However, the relevance of oligomerization of S100 proteins in vivo remains controversial except in situations where protein and metal concentrations are sufficiently high to match the conditions of the in vitro experiments. That stated, the high (millimolar) concentration of $\mathrm{Ca}^{2+}$ in the extracellular space implies that those S100 proteins whose oligomerization is promoted by $\mathrm{Ca}^{2+}$ may exist in higher order oligomeric states.

Like other EF-hand proteins, S100 proteins respond to $\mathrm{Ca}^{2+}$ signals by undergoing conformational changes upon ion binding, although the conformational changes are more modest relative to canonical EF-hand $\mathrm{Ca}^{2+}$ sensor proteins such as calmodulin (Nelson and Chazin, 1998; Nelson et al., 2002). Despite large variations in amino acid sequence (between $20 \%$ and $60 \%$ identity), the $\mathrm{Ca}^{2+}$-induced conformational change in all S100 proteins involves a significant shift in the orientation of Helix III (Figure 2) (Maler et al., 2002). Like other EF-hand $\mathrm{Ca}^{2+}$ sensors, this conformational change results in exposure of a hydrophobic patch that serves as the key factor driving binding of targets. Although they have very similar structural architectures, S100 proteins interact with a diverse set of cellular targets. This variability is accomplished by the fine-tuning within the target binding site of each S100 protein (Bhattacharya et al., 2004), in combination with their distinct cell-type, tissue-specific, and cell cycle-dependent expression. Current understanding of the cooperativity of $\mathrm{Ca}^{2+}$ binding and the structural rearrangements induced by $\mathrm{Ca}^{2+}$ binding have been reviewed in more detail elsewhere (Chazin, 2007; Ikura, 1996; Nelson and Chazin, 1998). Here we will focus on the unique ability of $\mathrm{S} 100$ proteins to bind transition metals in binding sites distinct from their $\mathrm{Ca}^{2+}$ binding sites (Heizmann and Cox, 1998), and the corresponding effects on structure, function and biochemical properties.

\section{BINDING OF ZINC}

The first report of $\mathrm{Zn}^{2+}$ binding to an S100 protein (S100B) was over thirty years ago (Baudier et al., 1984). Since that time binding of $\mathrm{Zn}^{2+}$ has been reported for S100A1, S100A2, S100A3, S100A5, S100A6, S100A7, S100A8/A9, S100A12, S100A16 and S100B (Table 1). $\mathrm{Zn}^{2+}$ binding S100 proteins can be classified into two categories: His-rich and Cys-rich. Sequence alignments, spectroscopic analysis, site-directed mutagenesis and high-resolution structures
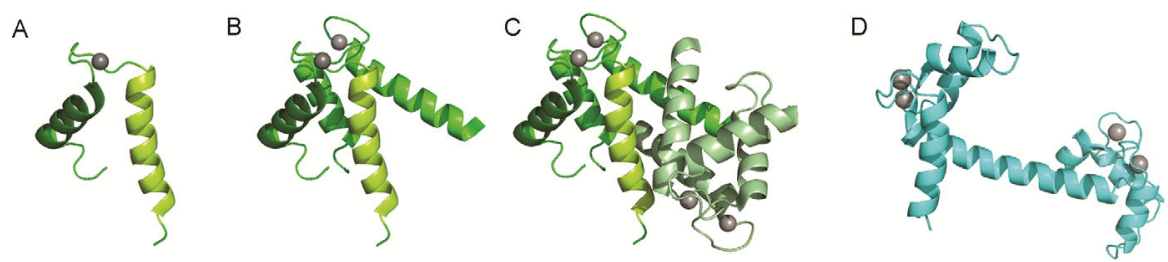

Figure 1 Structural features of S100 proteins. Ribbon diagrams of (A) an EF-hand motif, (B) an EF-hand domain, (C) the integration of two EF-hand domains into an S100 dimer, and (D) the alternate arrangement of two EF-hand domains in a prototypical EF-hand Ca ${ }^{2+}$ signal modulator. S100A12 was selected as the representative member of the S100 proteins and panels A, B and C were created using the Ca ${ }^{2+}-$ loaded protein (PDB entry $1 \mathrm{E} 8 \mathrm{~A}$ ). Panel D was created using $\mathrm{Ca}^{2+}$-loaded calmodulin (PDB entry 1CLL). The compact nature of the S100 homodimer relative to calmodulin implies a fundamentally different structural mechanism for transduction of $\mathrm{Ca}^{2+}$ signals. 
Table 1 S100 protein transition metal binding affinities

\begin{tabular}{|c|c|c|c|}
\hline Protein & $\begin{array}{l}\mathrm{Zn}^{2+} \\
K_{\mathrm{d}} \\
\end{array}$ & $\begin{array}{l}\mathrm{Mn}^{2+} \\
K_{\mathrm{d}} \\
\end{array}$ & $\begin{array}{l}\mathrm{Cu}^{2+} \\
K_{\mathrm{d}} \\
\end{array}$ \\
\hline S100A1 & $\begin{array}{l}<K_{\mathrm{d}}(\mathrm{S} 100 \mathrm{~B}) \\
\text { Trp fluorescence (Baudier, et al., 1986) }\end{array}$ & & \\
\hline $\mathrm{S} 100 \mathrm{~A} 2$ & $\begin{array}{l}49 \mathrm{nmol} \mathrm{L}^{-1}(-\mathrm{Ca}) \\
25 \mathrm{nmol} \mathrm{L}{ }^{-1}(+\mathrm{Ca}) \\
\text { Competition with Zn chelator (Koch et al., 2007) }\end{array}$ & & \\
\hline S100A3 & $\begin{array}{l}4 \mathrm{nmol} \mathrm{L}-1 \text { (-Ca) } \\
\text { Competition with Zn chelator (Fritz, et al., 2002) }\end{array}$ & & \\
\hline S100A5 & $\begin{array}{l}1-3 \mu \mathrm{mol} \mathrm{L}{ }^{-1}(-\mathrm{Ca}) \\
\text { Equilibrium gel filtration (Schäfer, et al., 2000) }\end{array}$ & & $\begin{array}{l}5 \mu \mathrm{mol} \mathrm{L}{ }^{-1}(-\mathrm{Ca}) \\
\text { Equilibrium gel filtration (Schäfer et } \\
\text { al., 2000) }\end{array}$ \\
\hline S100A6 & $\begin{array}{l}100 \mathrm{nmol} \mathrm{L}^{-1}(+\mathrm{Ca}) \\
\text { Fluorescence spectroscopy (Kordowska, et al., 1988) }\end{array}$ & & \\
\hline S100A7 & $\begin{array}{l}100 \mu \mathrm{mol} \mathrm{L}^{-1}(-\mathrm{Ca}) \\
\text { Equilibrium dialysis ( Vorum, et al., 1996) }\end{array}$ & & \\
\hline S100A8/A9 & $\begin{array}{l}3 \mathrm{nmol} \mathrm{L} \\
8 \mathrm{nmol} \mathrm{L} \\
8+\mathrm{Ca}) \text { Site } 1(\mathrm{Mn} / \mathrm{Zn}) \\
\text { ITC (isothermal Sitration calorimetry) (Damo, et al., 2013) } \\
K_{\mathrm{d} 1} \leq 10 \mathrm{pmol} \mathrm{L}^{-1} \text { (excess Ca) } \\
K_{\mathrm{d} 2} \leq 240 \mathrm{pmol} \mathrm{L}^{-1} \text { (excess Ca) } \\
\text { Fluorescent competition (Brophy, et al., 2012) }\end{array}$ & $\begin{array}{l}6 \mathrm{nmol} \mathrm{L}{ }^{-1}(+\mathrm{Ca}) \text { Site } 1(\mathrm{Mn} / \mathrm{Zn}) \\
\text { ITC (Damo, et al., 2013) } \\
K_{\mathrm{d} 1}=200 \mathrm{nmol} \mathrm{L}^{-1} \text { (excess Ca) } \\
K_{\mathrm{d} 2}=20 \mu \mathrm{mol} \mathrm{L}{ }^{-1} \text { (excess Ca) } \\
\text { EPR titrations ( Haydenet al., 2013) }\end{array}$ & \\
\hline S100A12 & $\begin{array}{l}2 \text { and } 100 \mu \mathrm{mol} \mathrm{L}^{-1}(-\mathrm{Ca}) \\
\text { Fluorescence spectroscopy (Moroz, et al., 2009) }\end{array}$ & & \\
\hline S100A13 & & & $\begin{array}{l}12 \text { and } 55 \mu \mathrm{mol} \mathrm{L} \mathrm{L}^{-1}(-\mathrm{Ca}) \\
62 \text { and } 120 \mu \mathrm{mol} \mathrm{L}{ }^{-1}(+\mathrm{Ca}) \\
\text { ITC (Sivaraja, et al., 2006) }\end{array}$ \\
\hline S100A16 & $\begin{array}{l}\sim 25 \mu \mathrm{mol} \mathrm{L}^{-1}(-\mathrm{Ca}) \\
\text { Equilibrium gel filtration (Sturchler et al., 2006) }\end{array}$ & & \\
\hline S100B & $\begin{array}{l}94 \mathrm{nmol} \mathrm{L}^{-1}(+\mathrm{Ca}) \\
\text { ITC (Wilder et al., 2003) }\end{array}$ & $\begin{array}{l}71 \mu \mathrm{mol} \mathrm{L}{ }^{-1}(-\mathrm{Ca}) \\
55.9 \mu \mathrm{mol} \mathrm{L} \mathrm{L}^{-1}(+\mathrm{Ca}) \\
\text { EPR and NMR ( Rustandi et al., 1988) }\end{array}$ & $\begin{array}{l}\text { Average } 0.46 \mu \mathrm{mol} \mathrm{L}^{-1}(-\mathrm{Ca}) \\
\text { Equilibrium filtration (Nishikawa et } \\
\text { al., 1997) }\end{array}$ \\
\hline
\end{tabular}

revealed a conserved binding motif for the proteins with His-rich sites (S100A6, S100A7, S100A8/A9, S100A12, S100A15, S100B), with 4 His residues, or 3 His and 1 Asp residues, at the dimer interface (Figure 3). The first $\mathrm{Zn}^{2+}$-bound structure was determined for S100A7 (Brodersen et al., 1999), and several additional $\mathrm{Zn}^{2+}$-bound structures from the His-rich group have been reported since. Since the proteins are dimers, each protein binds two $\mathrm{Zn}^{2+}$ at the two symmetrically disposed sites (Figure 2).

The $\mathrm{S} 100$ proteins capable of binding $\mathrm{Zn}^{2+}$ ions have affinities ranging from $K_{\mathrm{d}}=4 \mathrm{nmol} \mathrm{L}{ }^{-1}$ (S100A3) to $100 \mu \mathrm{mol}$ $\mathrm{L}^{-1}$ (S100A7) (Table 1). Direct comparisons among the reported affinities are not straightforward because the methods used and experimental conditions vary significantly. Importantly, although the majority of the $K_{\mathrm{d}}$ values fall within the $\mu \mathrm{mol} \mathrm{L} \mathrm{L}^{-1}$ range, $\mathrm{Zn}^{2+}$ concentrations inside and outside cells are low (e.g. 2-10 $\mathrm{nmol} \mathrm{L}^{-1}$ in the cytoplasm). Hence, the biological relevance of the binding of $\mathrm{Zn}^{2+}$ has yet to be established for most S100 proteins. Another significant factor in correlating in vitro measurements to functional context is the energetic coupling of interactions with metal co-factors and targets. This issue is well recognized for EF-hand proteins in the case of the substantial differences in $\mathrm{Ca}^{2+}$ affinity measured in the absence and presence of target proteins. Thus, an interplay between $\mathrm{Zn}^{2+}$ and $\mathrm{Ca}^{2+}$ binding to $\mathrm{S} 100$ proteins is expected. In fact, $\mathrm{Zn}^{2+}$ binding has been reported to raise the $\mathrm{Ca}^{2+}$ affinity of $\mathrm{S} 100 \mathrm{~B}$ by a factor of 10 and of S10012 by 1500 fold (Dell'Angelica et al., 1994; Moroz et al., 2011), to lower the $\mathrm{Ca}^{2+}$ affinity of S100A2 (Koch et al., 2007), and to have no effect on S100A5 (Schäfer et al., 2000).

The effects of $\mathrm{Zn}^{2+}$ binding on the structure of S100 proteins are in general rather modest. The basic dimeric architecture observed for the apo and $\mathrm{Ca}^{2+}$-loaded states is retained and overall the structures are very similar (all $\mathrm{C} \alpha$ RMSDs (root-mean-square deviations)<1.0 ) (Figure 2A). The structural changes induced by the binding of $\mathrm{Ca}^{2+}$ are substantially larger than the structural changes induced by the binding of $\mathrm{Zn}^{2+}$, i.e. $\mathrm{Zn}^{2+}$-bound apo proteins are more similar to the apo state than to the $\mathrm{Zn}^{2+}$-bound $\mathrm{Ca}^{2+}$-loaded state, and $\mathrm{Zn}^{2+}$-bound $\mathrm{Ca}^{2+}$-loaded proteins are more similar to the $\mathrm{Ca}^{2+}$-loaded state than to the $\mathrm{Zn}^{2+}$-bound apo state (Figure 2B). Detailed comparative analyses for structural differences between all states are possible for S100A7, for which structures have been determined in the apo, $\mathrm{Ca}^{2+}$-loaded, and $\mathrm{Ca}^{2+}, \mathrm{Zn}^{2+}$-loaded states, and for S100A12, for which structures have been determined in the apo, $\mathrm{Ca}^{2+}$-loaded, $\mathrm{Zn}^{2+}$-loaded, and $\mathrm{Ca}^{2+}, \mathrm{Cu}^{2+}$-loaded states. (The great similarity of $\mathrm{Zn}^{2+}$ and $\mathrm{Cu}^{2+}$ sites is discussed below in "Binding of copper") As seen in the $\mathrm{Zn}^{2+}$-loaded structures of S100A7 and S100A12, two $\mathrm{Zn}^{2+}$ ions are bound at the symmetrically disposed sites (Figure 4), coordinated by three His N2 atoms (His17, His86, His90) and an aspartate side chain (Asp24) (Figure 4B) (Brodersen et al., 1999; 

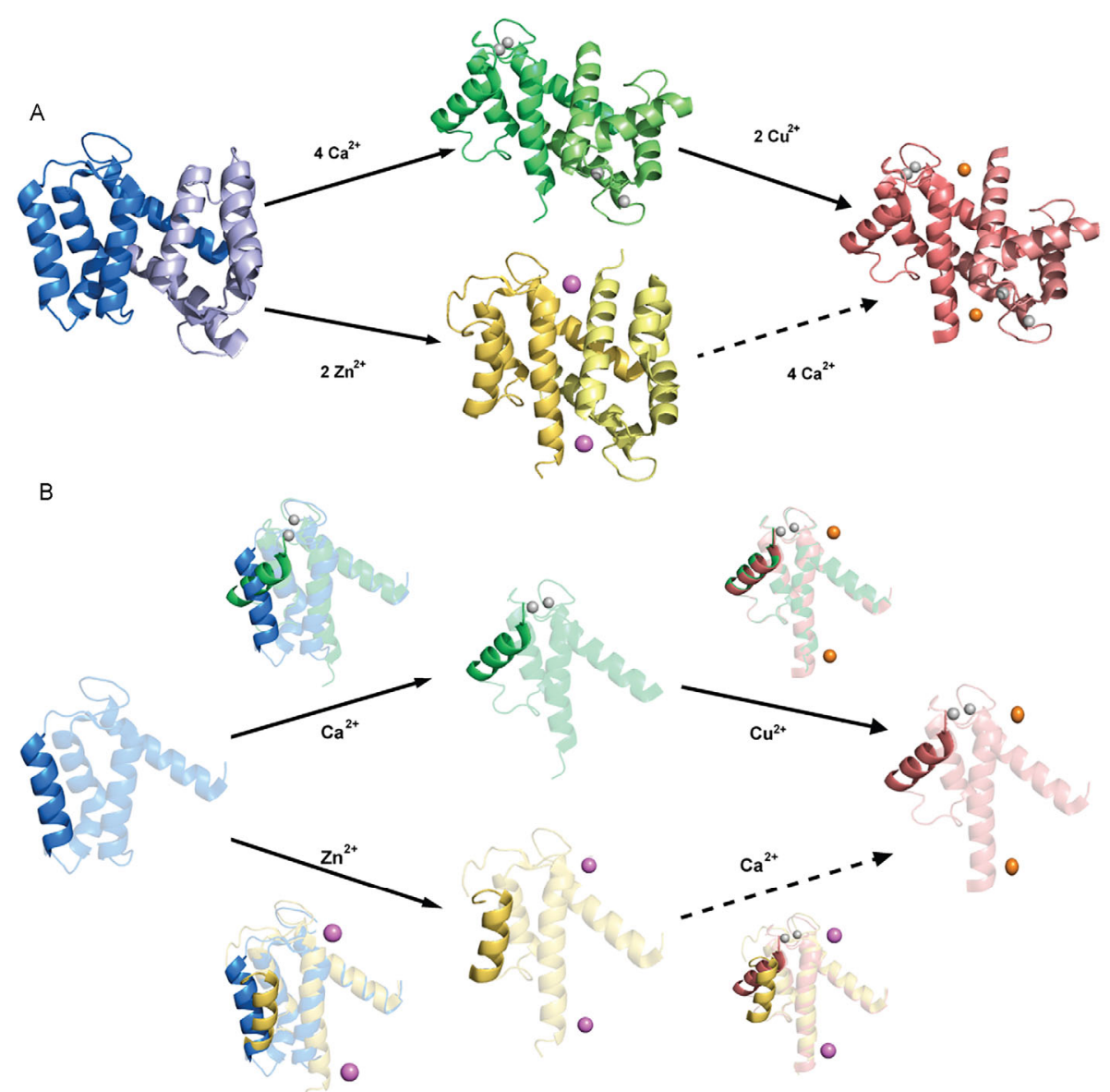

Figure 2 Three-dimensional structure of S100A12 and conformational changes induced by $\mathrm{Ca}^{2+}$ and transition metals. A, Ribbon diagrams of the apo, $\left(\mathrm{Ca}^{2+}\right)_{4},\left(\mathrm{Zn}^{2+}\right)_{2}$, and $\left(\mathrm{Ca}^{2+}\right)_{4},\left(\mathrm{Cu}^{2+}\right)_{2}$, states. B, Comparison of single sub-units to emphasize the differences in the packing of Helix III in different states. This reveals that the consequences of binding $\mathrm{Ca}^{2+}$ are much greater than those of binding transition metals. Images generated in pymol (DeLano, 2002) using coordinates deposited in the PDB for apo (2WCF), $\left(\mathrm{Ca}^{2+}\right)_{4}(1 \mathrm{E} 8 \mathrm{~A}),\left(\mathrm{Zn}^{2+}\right)_{2}(2 \mathrm{WC} 8)$ and $\left(\mathrm{Ca}^{2+}\right)_{4},\left(\mathrm{Cu}^{2+}\right)_{2}(1 \mathrm{ODB})$.

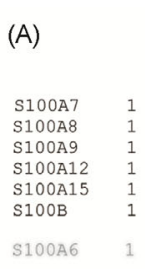

(B)

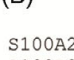

S100A2
S100A3
S100A4
S100 EF-hand

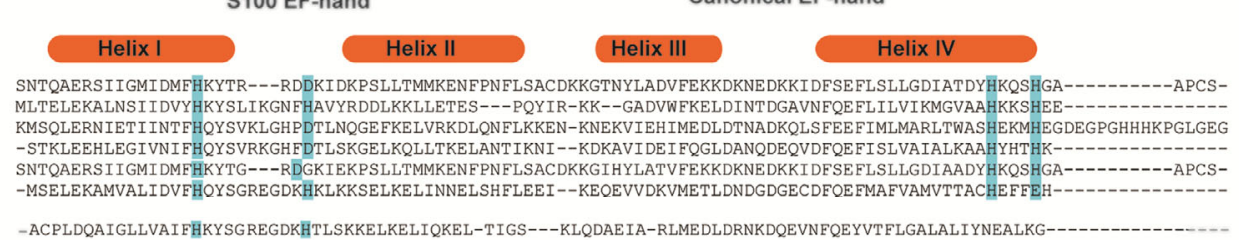

S100 EF-hand

Canonical EF-hand

Figure 3 Alignments of S100 proteins containing transition metal binding sites. Structure based sequence alignment of S100 proteins from the His-rich (upper panel) and Cys-rich (lower panel) categories. Conserved residues in His-rich sites are highlighted with teal background, and those in Cys-rich sites in red background. Note the high degree of conservation in the His-rich proteins compared to the Cys-rich proteins. The alignments were generated using PROMALS3D (Pei et al., 2008).

Leon et al., 2009). In all cases, the primary effect of $\mathrm{Zn}^{2+}$ is to alter the orientation of Helix III (Figure 2B). Interestingly, $\mathrm{Zn}^{2+}$-binding results in poor electron density for residues 62-67 in S100A12, even though these are well defined in the structure of the apo state (Moroz et al., 2009a). This led to the proposal that flexibility in this loop region may be induced by $\mathrm{Zn}^{2+}$, and thereby facilitate the $\sim 1500$-fold increase in the affinity of S100A12 for $\mathrm{Ca}^{2+}$.

The binding of $\mathrm{Zn}^{2+}$ has been extensively studied for S100B, most notably in conjunction with the p53 tumor suppressor protein (Lin et al., 2004). S100B has high affinity for $\mathrm{Zn}^{2+}\left(K_{\mathrm{d}} \sim 90 \mathrm{nmol} \mathrm{L}^{-1}\right)$. NMR spectroscopy and site 

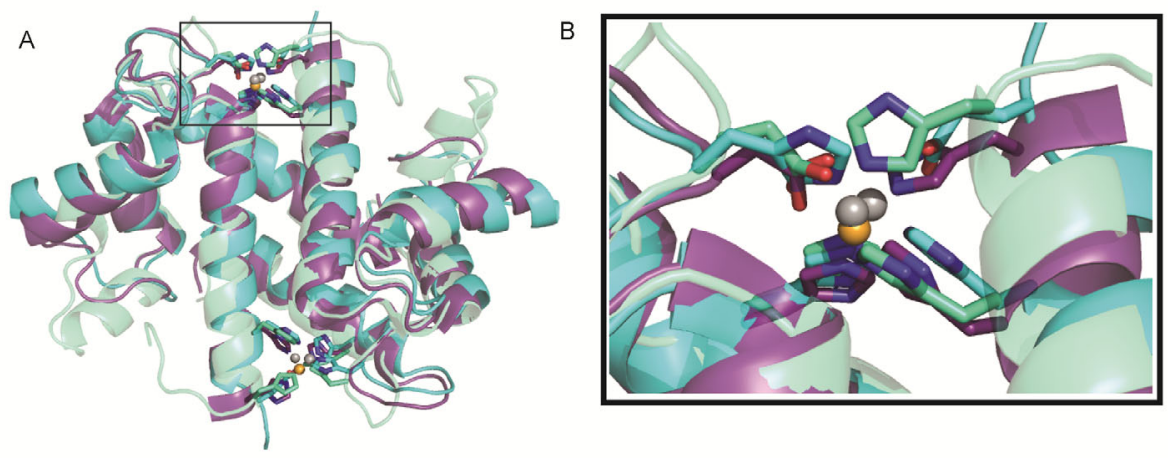

Figure 4 Structural similarity of tetrahedral zinc and copper binding sites in $\mathrm{S} 100$ proteins. A, Overlay of the structures of $\left(\mathrm{Ca}^{2+}\right)_{4},\left(\mathrm{Zn}^{2+}\right)_{2}-\mathrm{S} 100 \mathrm{~A} 7($ light green), $\left(\mathrm{Ca}^{2+}\right)_{4},\left(\mathrm{Zn}^{2+}\right)_{2}$-S100B (teal) and $\left(\mathrm{Ca}^{2+}\right)_{4},\left(\mathrm{Cu}^{2+}\right)_{2}$-S100A12 (purple) showing that the transition metal ions are chelated in a similar manner by side chains in the same position in the sequence. $\mathrm{B}$, Zoom in on the tetrahedral $\mathrm{Zn}^{2+}$ and $\mathrm{Cu}^{2+}$ sites showing the similar spatial disposition of the $3 \mathrm{His}$ and $1 \mathrm{Asp}$ chelating side chains. The $\mathrm{Zn}^{2+}$ and $\mathrm{Cu}^{2+}$ ions are colored gray and orange, respectively. Images generated in pymol (DeLano, 2002) using PDB coordinates deposited for $\left(\mathrm{Ca}^{2+}\right)_{4},\left(\mathrm{Zn}^{2+}\right)_{2}-\mathrm{S} 100 \mathrm{~A} 7$ (2PSR), $\left(\mathrm{Ca}^{2+}\right)_{4},\left(\mathrm{Zn}^{2+}\right)_{2}-\mathrm{S} 100 \mathrm{~B}(3 \mathrm{D} 0 \mathrm{Y})$, and $\left(\mathrm{Ca}^{2+}\right)_{4},\left(\mathrm{Cu}^{2+}\right)_{2}-\mathrm{S} 100 \mathrm{~A} 12(1 \mathrm{ODB})$.

directed mutagenesis indicated that $\mathrm{Zn}^{2+}$ binding occurs in a similar manner to other S100 proteins with His-rich transition metal binding sites, namely His15/His 25 from one subunit and His85/His89 from the other subunit. However, $\mathrm{Zn}^{2+}$ binding to $\mathrm{S} 100 \mathrm{~B}$ causes a more pronounced kink in Helix IV than in S100A7 and S100A12 (Wilder et al., 2005). $\mathrm{Zn}^{2+}$ binding has been shown to increase the affinity for target peptides over the effect of $\mathrm{Ca}^{2+}$ alone (Wilder et al., 2003). Structural coupling of the $\mathrm{Zn}^{2+}$ and target binding sites has been found, and this information has been incorporated into the design of S100B inhibitors of the interaction with targets such as p53. Co-crystal structures with pentamidine, an S100B inhibitor known to bind in the target binding site, were determined for both the $\mathrm{Ca}^{2+}$ - and $\mathrm{Ca}^{2+}$, $\mathrm{Zn}^{2+}$-loaded states (Charpentier et al., 2008; Charpentier et al., 2009). These studies motivated the generation of new inhibitors engineered to disrupt the $\mathrm{Zn}^{2+}$-binding residues and $\mathrm{Zn}^{2+}$-induced conformational changes in S100B (Cavalier et al., 2014).

The role of oligomerization in the function of S100 proteins has been vigorously debated. There is ample evidence of $\mathrm{Ca}^{2+}$ - and $\mathrm{Zn}^{2+}$-induced oligomerization in vitro including a number of crystal structures with high order oligomerization states (Moroz et al., 2002, 2009a; Ostendorp et al., 2007) and a mass spectrometry study of $\mathrm{Zn}^{2+}$-induced tetramerization of CP (Vogl et al., 2006). However, there is very little evidence of the functional significance of oligomerization from experiments in cells; this is an area that is in great need of further investigation. A role for oligomerization of S100 proteins is most likely in association with the extracellular functions of S100 proteins as activators of cell surface receptors (Malashkevich et al., 2010; Moroz et al., 2009a; Ostendorp et al., 2011, 2007). The most well studied of these receptors is receptor for advanced glycation end products (RAGE), which has been shown to bind several S100 proteins at the cell surface and elicit an intracellular response via the $\mathrm{NF}-\kappa \mathrm{B}$ signaling pathway. A role for $\mathrm{Zn}^{2+}$ in the interaction of S100A7 and
S100A15 with RAGE has been proposed (Murray et al., 2012; Wolf et al., 2008).

The Cys-rich $\mathrm{Zn}^{2+}$ binding $\mathrm{S} 100$ proteins (S100A2, S100A3, S100A4) are much less studied than the His-rich group (Moroz et al., 2011). One challenge is the absence of a conserved motif evident from alignment of these proteins (Figure 3). The consensus view is that the Cys-rich sites coordinate $\mathrm{Zn}^{2+}$ ions with either 4 Cys residues or $3 \mathrm{Cys}$ and 1 His residue (Moroz et al., 2011). A second challenge is that Cys-rich sites will be susceptible to redox reactions that disrupt disulfides and modulate $\mathrm{Zn}^{2+}$-binding. Obtaining high resolution $\mathrm{X}$-ray data on the Cys-rich $\mathrm{Zn}^{2+}$-binding S100 proteins is difficult due to improper folding during in vitro bacterial overexpression. In fact, the majority of S100A2 and S100A4 structures were determined with Cys residues mutated to facilitate protein production. The protein production obstacle was overcome for S100A3 by producing the protein from insect cells, which promotes proper disulfide formation and folding (Kizawa et al., 2013a, b). Crystallization of S100A3 produced in this manner identified two disulfide bonds not previously identified. These disulfides apparently play a critical structural role, as disruption of either disulfide significantly affected the $\mathrm{Ca}^{2+}$ affinity (Unno et al., 2011). Unfortunately, electron density for $\mathrm{Zn}^{2+}$ ions was too weak to formally assign their presence in the structure. However, a single Cys-rich $\mathrm{Zn}^{2+}$ site could be readily modeled, and $\mathrm{Zn}^{2+}$ binding was proposed to be important for folding and formation of the critical disulfide bonds in S100A3. Since the majority of analyses in the past 15 years utilized recombinant protein expressed in E. coli, future studies using proteins produced from eukaryotic expression systems may enhance understanding of $\mathrm{Zn}^{2+}$ binding to S100 proteins from the Cys-rich group.

\section{BINDING OF COPPER}

Due to their similar chemical properties, copper is anticipated to bind to most zinc binding sites in proteins. It was 
therefore natural to examine the binding of copper $\left(\mathrm{Cu}^{2+}\right)$ to $\mathrm{S} 100$ proteins when $\mathrm{Zn}^{2+}$ binding was first noted for S100B (Nishikawa et al., 1997). In that report, four $\mathrm{Cu}^{2+}$ ions were identified per S100B dimer with an average dissociation constant $\left(K_{\mathrm{d}}\right)$ of $0.46 \mu \mathrm{mol} \mathrm{L}{ }^{-1}$. However, subsequent structure-based alignments predicted that there are only two high affinity sites and that the two others are weak non-specific sites (Nishikawa et al., 1997). Ion competition experiments demonstrated that the $\mathrm{Cu}^{2+}$ ions could be displaced by $\mathrm{Zn}^{2+}$, but not $\mathrm{Ca}^{2+}$. Thus, as expected, the binding of $\mathrm{Cu}^{2+}$ by $\mathrm{S} 100$ proteins closely resembles binding of $\mathrm{Zn}^{2+}$, with a few noticeable exceptions.

Important insight into binding of $\mathrm{Cu}^{2+}$ by $\mathrm{S} 100$ proteins was provided by the $\mathrm{X}$-ray crystal structure of $\mathrm{Ca}^{2+}$, $\mathrm{Cu}^{2+}$-S100A12 (Moroz et al., 2003). The overall conformational change induced by the binding of $\mathrm{Cu}^{2+}$ is very small; the $\mathrm{C} \alpha$ RMSD of the $\mathrm{Ca}^{2+}$ versus the $\mathrm{Ca}^{2+}, \mathrm{Cu}^{2+}$ state is 0.35 $\AA$. Interestingly, both the apo and $\mathrm{Ca}^{2+}, \mathrm{Cu}^{2+}$-bound states have well defined electron density out to Lys90, but His87-Lys90 is disordered when only $\mathrm{Ca}^{2+}$ is bound (Moroz et al., 2003). The $\mathrm{Cu}^{2+}$ ion is bound in a canonical $\mathrm{Cu}^{2+}$ site ( 3 His residues along with either an oxygen or sulfur containing residue), with coordination by His15 and Asp25 from one subunit and His85 and His89 from the other subunit, identical to the coordination of $\mathrm{Zn}^{2+}$. In fact, $\mathrm{Ca}^{2+}, \mathrm{Cu}^{2+}$ and $\mathrm{Ca}^{2+}, \mathrm{Zn}^{2+}$ structures are very similar even when comparing between different S100 proteins (Figure 4): the $\mathrm{C} \alpha$ RMSD between $\mathrm{Ca}^{2+}, \mathrm{Cu}^{2+}-\mathrm{S} 100 \mathrm{~A} 12$ and $\mathrm{Ca}^{2+}, \mathrm{Zn}^{2+}$ $\mathrm{S} 100 \mathrm{~A} 7$ is only $0.72 \AA$, and for $\mathrm{Ca}^{2+}, \mathrm{Zn}^{2+}-\mathrm{S} 100 \mathrm{~B}$ only 0.42 $\AA$ (Charpentier et al., 2008). The great similarity in the structures of the $\mathrm{Cu}^{2+}$ and $\mathrm{Zn}^{2+}$-loaded protein implies that $\mathrm{Cu}^{2+}$ will bind to the $\mathrm{Zn}^{2+}$ sites in other $\mathrm{S} 100$ proteins (Moroz et al., 2003, 2009b).

The structural consequences of $\mathrm{Cu}^{2+}$ binding to S100A13 have been investigated using solution NMR (Arnesano et al., 2005). Comparisons between apo, $\mathrm{Ca}^{2+}$-loaded and $\mathrm{Ca}^{2+}$, $\mathrm{Cu}^{2+}$-loaded S100A13 revealed $\mathrm{Cu}^{2+}$ causes an additional, minor opening of the Helix III-IV interface relative to the $\mathrm{Ca}^{2+}$-loaded state. The binding site has several unique characteristics compared to other S100 proteins, including the location of the site, as well as the ligand coordination and solvent accessibility to the $\mathrm{Cu}^{2+}$ ion. NMR titrations of $\mathrm{Ca}^{2+}-\mathrm{S} 100 \mathrm{~A} 13$ with paramagnetic $\mathrm{Cu}^{2+}$ ions were used to propose Glu4, Glu8, Glu11, and His48 as the $\mathrm{Cu}^{2+}$-chelating side chains. These correlated with electron paramagnetic resonance (EPR) studies that assigned the $\mathrm{Cu}^{2+}$ coordination as pseudo-tetragonal with nitrogen and oxygen donor atoms. An unexpected aspect of their analysis was that the $\mathrm{Cu}^{2+}$ ions are completely exposed to solvent, unlike the typical transition metal sites that are buried within the S100 proteins (Arnesano et al., 2005). The authors suggested that exposure of the metal may help regulate the interaction of S100A13 with target proteins, but no data was provided in support of this speculation.

$\mathrm{Zn}^{2+}$ and $\mathrm{Cu}^{2+}$ ions have been proposed to induce con- formational changes in S100 proteins (e.g. (Vogl et al., 2006)), although the crystal structures described above and shown in Figure 4 reveal these changes are very modest. Nevertheless, $\mathrm{Cu}^{2+}$ binding has the potential to alter the structure of S100 proteins and therefore oligomerization and interactions with target proteins. Although $\mathrm{Zn}^{2+}$ induced oligomerization of $\mathrm{S} 100$ proteins has been explored in vitro, the sole study of the effect of $\mathrm{Cu}^{2+}$ reported no changes in oligomerization of the S100A8/S100A9 heterodimer (Vogl et al., 2006). The only study of the effect of $\mathrm{Cu}^{2+}$ on receptor binding revealed stimulation of the interaction of S100A4 with RAGE (Haase-Kohn et al., 2011). Although the dearth of information about the effects of $\mathrm{Cu}^{2+}$ on physical properties should be addressed, there is even greater urgency to establish if $\mathrm{Cu}^{2+}$ binding has any physiological role in S100 protein function.

\section{BINDING OF MANGANESE}

Manganese is an important transition metal in biological systems (Sigel and Sigel, 2000). It is a critical component in certain enzymatic processes (e.g. phosphorylation) and in the oxidative stress response. Recently, manganese regulation has been recognized for its essential role in contributing to the virulence of pathogenic organisms (reviewed in (Zackular et al., 2015)), with an explicit role played by the S100A8/S100A9 heterodimer, calprotectin (CP). As will be summarized below, high affinity binding of $\mathrm{Mn}^{2+}$ to $\mathrm{S} 100$ proteins is unique to $\mathrm{CP}$.

All pathogenic organisms require essential nutrients from the host to survive and proliferate, including transition metals. A mechanism termed nutritional immunity, which involves sequestering the essential nutrients from the pathogen, is used by the host to fight infection. A role for transition metals besides $\mathrm{Fe}$ in nutritional immunity was first discovered when inductively coupled plasma mass spectrometry (ICP-MS) analysis showed that there are distinct differences in the transition metal content in and around tissues infected with Staphylococcus aureus (Corbin et al., 2008). In particular, staphylococcal abscesses were found to be devoid of $\mathrm{Zn}^{2+}$ and $\mathrm{Mn}^{2+}$ ions. Proteomic imaging of the tissue revealed high concentrations of the S100A8 and S100A9 CP subunits surrounding the sites of infection. Subsequent work confirmed that $\mathrm{CP}$, which is present in very large abundance in certain innate immune cells such as neutrophils, plays a critical role in the innate immune response to pathogens, functioning via the nutritional immunity mechanism through the high affinity binding and sequestration of $\mathrm{Zn}^{2+}$ and $\mathrm{Mn}^{2+}$ (Corbin et al., 2008; Zackular et al., 2015). Subsequent studies using CP knockout mice have demonstrated that $\mathrm{CP}$ inhibits growth from other pathogenic organisms, including Acinetobacter baumannii, Candida albicans, Aspergillus fumigatus and Helicobacter pylori (Clark et al., 2016; Gaddy et al., 2014; Hood et al., 2012; Kehl-Fie et al., 2011, 2013). 
Based on the available information on the binding of $\mathrm{Zn}^{2+}$ to $\mathrm{S} 100$ proteins, it was assumed that $\mathrm{Mn}^{2+}$ bound to similar sites and completed its coordination shell with waters. Importantly, early studies showed that $\mathrm{CP}$ bound 2 equivalents of $\mathrm{Zn}^{2+}$ ions, but only one equivalent of $\mathrm{Mn}^{2+}$. This was confirmed by site-directed mutagenesis studies that revealed $\mathrm{Mn}^{2+}$ binds to the 4-His site (His17 and His27 from S100A8, His91 and His95 from S100A9) (Kehl-Fie et al., 2011). Site directed mutagenesis experiments also showed that two His residues in the S100A9 C-terminal tail (His103, His105) are required for high affinity $\mathrm{Mn}^{2+}$ binding (Brophy et al., 2013; Damo et al., 2013). As noted above, there is energetic coupling of transition metal binding and $\mathrm{Ca}^{2+}$ binding; the $\mathrm{Mn}^{2+}$ affinity of $\mathrm{CP}$ under limited $\mathrm{Ca}^{2+}$ availability $\left(K_{\mathrm{d}}>550 \mathrm{nmol} \mathrm{L}{ }^{-1}\right)$ is weaker than in the presence of $\mathrm{Ca}^{2+}\left(K_{\mathrm{d}}=194 \mathrm{nmol} \mathrm{L}{ }^{-1}\right)$ (Brophy and Nolan, 2015; Damo et al., 2013). The origin of this allosteric effect has yet to be established, although it is conceivable that binding of $\mathrm{Ca}^{2+}$ results in reorganization of the structure and/or dynamics of key side chains to better facilitate $\mathrm{Mn}^{2+}$ binding. Notably, the only known function of transition metal binding for $\mathrm{CP}$ is in the extracellular milieu where $\mathrm{Ca}^{2+}$ concentrations are very high (in the $\mathrm{mmol} \mathrm{L}^{-1}$ range) and $\mathrm{CP}^{\prime} \mathrm{C}^{2+}$ sites will invariably be filled, so the physiological relevance of the difference in $\mathrm{Mn}^{2+}$ affinities in the absence and presence of $\mathrm{Ca}^{2+}$ remains uncertain.

The critical step forward in characterizing the binding of $\mathrm{Mn}^{2+}$ to CP was the determination of the crystal structure of $\left(\mathrm{Ca}^{2+}\right)_{4}, \mathrm{Mn}^{2+}-\mathrm{CP}$ (Brophy et al., 2013; Damo et al., 2013; Gagnon et al., 2015) (Figure 5). Comparison with the $\left(\mathrm{Ca}^{2+}\right)_{4}$-CP structure (Korndorfer et al., 2007) revealed there are no large conformational changes. The C $\alpha$ RMSD between the two structures is $0.29 \AA$ for the S100A8 subunit and $0.24 \AA$ for the S100A9 subunit. Previous crystal struc- tures of $\mathrm{CP}$ were disordered beyond His95 in the C-terminal tail; only with the addition of $\mathrm{Mn}^{2+}$ ions in the crystal structure was electron density out to Gly112 well defined. This correlates with the direct observation of chelation of the $\mathrm{Mn}^{2+}$ ion by the His103 and His 105 side chains. Typically, $\mathrm{Mn}^{2+}$ is coordinated by 5 or 6 ligands. The $\mathrm{Mn}^{2+}$ site in CP is the only example of 6-His octahedral coordination of $\mathrm{Mn}^{2+}$ in the Protein DataBank (PDB). CP is the only member of the $\mathrm{S} 100$ protein group that is capable of high affinity binding of $\mathrm{Mn}^{2+}$ (Brophy et al., 2013; Brophy and Nolan, 2015; Damo et al., 2013); the crystal structure shows that this is due to the unique combination of the 4-His transition metal binding site at the heterodimer interface (Figure 5) and the His-rich C-terminal tail that is unique to S100A9.

\section{BINDING OF OTHER TRANSITION METALS}

Robust $\mathrm{Zn}^{2+}$ binding at the dimerization interface led to studies of the ability of S100 proteins to bind other first-row transition metals besides $\mathrm{Mn}^{2+}$ and $\mathrm{Cu}^{2+}$, but no significant affinities were observed (Fritz et al., 1998). A recent study reports that $\mathrm{CP}$ is capable of sequestering ferrous $\left(\mathrm{Fe}^{2+}\right)$ iron from pathogenic growth media, in parallel to sequestration of $\mathrm{Mn}^{2+}$ and $\mathrm{Zn}^{2+}$ (Nakashige et al., 2015). However, the relevance of ferrous iron to the host-pathogen interaction has not been firmly established, and existing in vivo data do not support a role for $\mathrm{CP}$ in the sequestration of iron as a defense strategy against infection (Corbin et al., 2008; Damo et al., 2013). Sub-picomolar affinity for $\mathrm{Fe}^{2+}$ was reported, with coordination via an uncommon 6-His coordination assigned based on Mössbauer spectroscopy (Nakashige et al., 2015) that presumably corresponds to the unique $\mathrm{Mn}^{2+}$ binding site in CP. If such very high $\mathrm{CP}$ affinity for $\mathrm{Fe}^{2+} \mathrm{CP}$ is validated, a role for $\mathrm{CP}$-dependent $\mathrm{Fe}^{2+}$ sequestration during infection will need to be investigated.
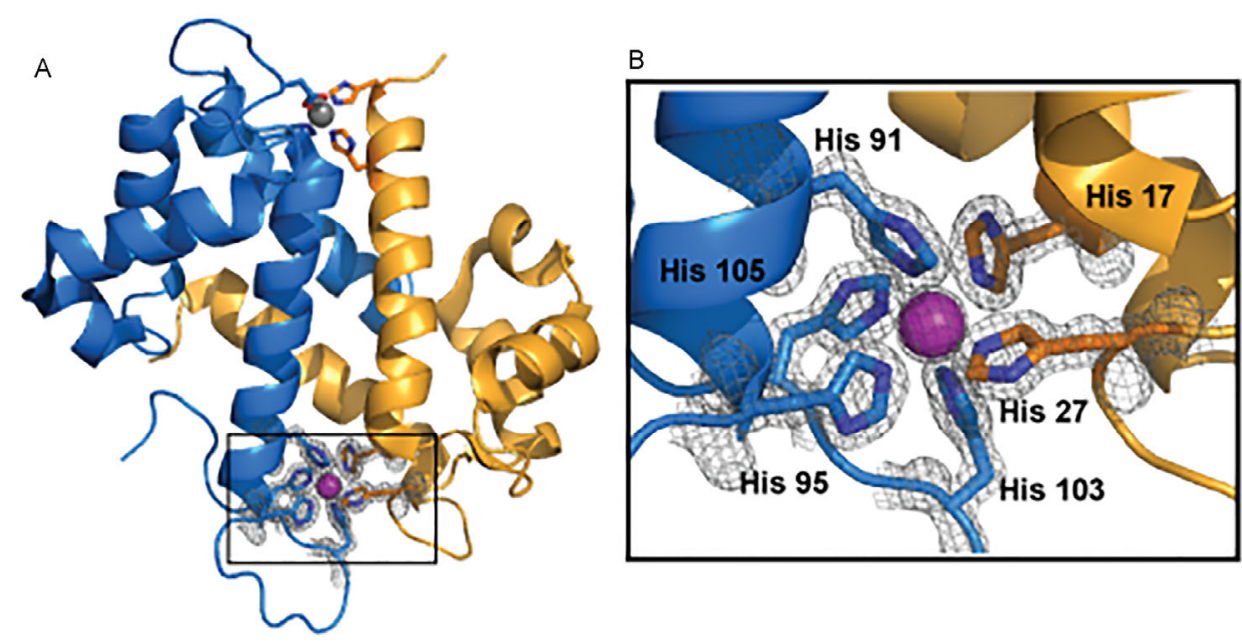

Figure 5 Three-dimensional structure of calprotectin highlighting the unique manganese binding site. The S100A8 subunit is colored blue, the S100A9 subunit gold, and the $\mathrm{Mn}^{2+}$ ion purple. An additional low occupancy $\mathrm{Mn}^{2+}$ ion is shown in gray. Images generated in pymol (DeLano, 2002) using coordinates deposited in the PDB for $\left(\mathrm{Ca}^{2+}\right)_{4},\left(\mathrm{Mn}^{2+}\right)-\mathrm{CP}(4 \mathrm{GGF})$. 


\section{CONCLUDING REMARKS}

The ability of S100 proteins to bind transition metals at sites separate from their $\mathrm{Ca}^{2+}$ binding sites highlights the complexities of their biochemical actions and the everchanging environments within and outside cells. Structural analyses have identified specific conformational changes induced by $\mathrm{Ca}^{2+}$ and transition metals. However, information is urgently needed to understand if and how transition metals modulate S100 protein interactions with their targets. Questions regarding oligomerization state and whether transition metal binding is needed for signaling to occur also need to be addressed. Substantial evidence for S100 proteins in human disease suggests there is significant potential in pursuing S100 proteins as therapeutic targets and motivates ongoing efforts in multiple laboratories to develop S100 protein-specific inhibitors.

Compliance and ethics The author(s) declare that they have no conflict of interest.

Acknowledgements This work was supported by operating grant (RO1 AI101171 to Eric P. Skaar and Walter J. Chazin), and institutional training grant (T32 ES007028 support for Benjamin A. Gilston) from the US National Institutes of Health.

Arnesano, F., Banci, L., Bertini, I., Fantoni, A., Tenori, L., and Viezzoli, M.S. (2005). Structural interplay between calcium(II) and copper(II) binding to S100A13 protein. Angew Chem Int Ed Engl 44, 6341-6344.

Baudier, J., Glasser, N., and Gerard, D. (1986). Ions binding to s100 proteins. I. Calcium- and zinc-binding properties of bovine brain s100 alpha alpha, s100a (alpha beta), and s100b (beta beta) protein: $\mathrm{Zn}^{2+}$ regulates $\mathrm{Ca}^{2+}$ binding on $\mathrm{s} 100 \mathrm{~b}$ protein. J Biol Chem 261, 8192-8203.

Baudier, J., Glasser, N., Haglid, K., and Gerard, D. (1984). Purification, characterization and ion binding properties of human brain $\mathrm{S} 100 \mathrm{~b}$ protein. Biochim Biophys Acta 790, 164-173.

Baudier, J., Holtzscherer, C., and Gerard, D. (1982). Zinc-dependent affinity chromatography of the $\mathrm{S} 100 \mathrm{~b}$ protein on phenyl-Sepharose. A rapid purification method. FEBS Lett 148, 231-234.

Bhattacharya, S., Bunick, C.G., and Chazin, W.J. (2004). Target selectivity in EF-hand calcium binding proteins. Biochim Biophys Acta 1742, 69-79.

Brodersen, D.E., Nyborg, J., and Kjeldgaard, M. (1999). Zinc-binding site of an $\mathrm{S} 100$ protein revealed. Two crystal structures of $\mathrm{Ca}^{2+}$-bound human psoriasin (S100A7) in the $\mathrm{Zn}^{2+}$-loaded and $\mathrm{Zn}^{2+}$-free states. Biochemistry 38, 1695-1704.

Brophy, M.B., and Nolan, E.M. (2015). Manganese and microbial pathogenesis: sequestration by the Mammalian immune system and utilization by microorganisms. ACS Chem Biol 10, 641-651.

Brophy, M.B., Hayden, J.A., and Nolan, E.M. (2012). Calcium ion gradients modulate the zinc affinity and antibacterial activity of human calprotectin. J Am Chem Soc 134, 18089-18100.

Brophy, M.B., Nakashige, T.G., Gaillard, A., and Nolan, E.M. (2013). Contributions of the S100A9 C-terminal tail to high-affinity $\mathrm{Mn}(\mathrm{II})$ chelation by the host-defense protein human calprotectin. J Am Chem Soc 135, 17804-17817.

Bunick, C.G., Nelson, M.R., Mangahas, S., Hunter, M.J., Sheehan, J.H., Mizoue, L.S., Bunick, G.J., and Chazin, W.J. (2004). Designing sequence to control protein function in an EF-hand protein. J Am Chem Soc 126, 5990-5998.

Cavalier, M.C., Pierce, A.D., Wilder, P.T., Alasady, M.J., Hartman, K.G., Neau, D.B., Foley, T.L., Jadhav, A., Maloney, D.J., Simeonov, A.,
Toth, E.A., and Weber, D.J. (2014). Covalent small molecule inhibitors of $\mathrm{Ca}^{2+}$-bound S100B. Biochemistry 53, 6628-6640.

Charpentier, T.H., Wilder, P.T., Liriano, M.A., Varney, K.M., Pozharski, E., MacKerell, A.D., Jr., Coop, A., Toth, E.A., and Weber, D.J. (2008). Divalent metal ion complexes of S100B in the absence and presence of pentamidine. J Mol Biol 382, 56-73.

Charpentier, T.H., Wilder, P.T., Liriano, M.A., Varney, K.M., Zhong, S., Coop, A., Pozharski, E., MacKerell, A.D., Jr., Toth, E.A., and Weber, D.J. (2009). Small molecules bound to unique sites in the target protein binding cleft of calcium-bound $\mathrm{S} 100 \mathrm{~B}$ as characterized by nuclear magnetic resonance and X-ray crystallography. Biochemistry 48, 6202-6212.

Chazin, W.J. (2007). The impact of X-ray crystallography and NMR on intracellular calcium signal transduction by EF-hand proteins: crossing the threshold from structure to biology and medicine. Sci STKE 2007, pe27.

Clark, H.L., Jhingran, A., Sun, Y., Vareechon, C., de Jesus Carrion, S., Skaar, E.P., Chazin, W.J., Calera, J.A., Hohl, T.M., and Pearlman, E. (2016). Zinc and manganese chelation by neutrophil S100A8/A9 (Calprotectin) limits extracellular Aspergillus fumigatus hyphal growth and corneal infection. J Immunol 196, 336-344.

Corbin, B.D., Seeley, E.H., Raab, A., Feldmann, J., Miller, M.R., Torres, V.J., Anderson, K.L., Dattilo, B.M., Dunman, P.M., Gerads, R., Caprioli, R.M., Nacken, W., Chazin, W.J., and Skaar, E.P. (2008). Metal chelation and inhibition of bacterial growth in tissue abscesses. Science 319, 962-965.

Damo, S.M., Kehl-Fie, T.E., Sugitani, N., Holt, M.E., Rathi, S., Murphy, W.J., Zhang, Y., Betz, C., Hench, L., Fritz, G., Skaar, E.P., and Chazin, W.J. (2013). Molecular basis for manganese sequestration by calprotectin and roles in the innate immune response to invading bacterial pathogens. Proc Natl Acad Sci USA 110, 3841-3846.

DeLano, W.L. (2002). The PyMOL molecular graphics system (Palo Alto: DeLano Scientific).

Dell'Angelica, E.C., Schleicher, C.H., and Santome, J.A. (1994). Primary structure and binding properties of calgranulin C, a novel S100-like calcium-binding protein from pig granulocytes. J Biol Chem 269, 28929-28936.

Donato, R. (2003). Intracellular and extracellular roles of S100 proteins. Microsc Res Tech 60, 540-551.

Donato, R., Cannon, B.R., Sorci, G., Riuzzi, F., Hsu, K., Weber, D.J., and Geczy, C.L. (2013). Functions of S100 proteins. Curr Mol Med 13, 24-57.

Fritz, G., Heizmann, C.W., and Kroneck, P.M. (1998). Probing the structure of the human $\mathrm{Ca}^{2+}$ - and $\mathrm{Zn}^{2+}$-binding protein S100A3: spectroscopic investigations of its transition metal ion complexes, and three-dimensional structural model. Biochim Biophys Acta 1448, 264-276.

Fritz, G., Mittl, P.R., Vasak, M., Grutter, M.G., and Heizmann, C.W. (2002) The crystal structure of metal-free human EF-hand protein S100A3 at 1.7-A resolution. J Biol Chem 277, 33092-33098.

Günter, F., and Heizmann, C.W. (2006). 3D Structures of the Calcium and Zinc Binding S100 Proteins. In Handbook of Metallproteins.

Gaddy, J.A., Radin, J.N., Loh, J.T., Piazuelo, M.B., Kehl-Fie, T.E., Delgado, A.G., Ilca, F.T., Peek, R.M., Cover, T.L., Chazin, W.J., Skaar, E.P., and Scott Algood, H.M. (2014). The host protein calprotectin modulates the Helicobacter pylori cag type IV secretion system via zinc sequestration. PLoS Pathog 10, e1004450.

Gagnon, D.M., Brophy, M.B., Bowman, S.E., Stich, T.A., Drennan, C.L., Britt, R.D., and Nolan, E.M. (2015). Manganese binding properties of human calprotectin under conditions of high and low calcium: X-ray crystallographic and advanced electron paramagnetic resonance spectroscopic analysis. J Am Chem Soc 137, 3004-3016.

Gribenko, A.V., and Makhatadze, G.I. (1998). Oligomerization and divalent ion binding properties of the S100P protein: a $\mathrm{Ca}^{2+} / \mathrm{Mg}^{2+}$-switch model. J Mol Biol 283, 679-694.

Haase-Kohn, C., Wolf, S., Lenk, J., and Pietzsch, J. (2011). Copper-mediated cross-linking of S100A4, but not of S100A2, results in proinflammatory effects in melanoma cells. Biochem Biophys Res Commun 413, 494-498. 
Haley, K.P., Delgado, A.G., Piazuelo, M.B., Mortensen, B.L., Correa, P., Damo, S.M., Chazin, W.J., Skaar, E.P., and Gaddy, J.A. (2015). The human antimicrobial protein calgranulin $\mathrm{C}$ participates in control of Helicobacter pylori growth and regulation of virulence. Infect Immun 83, 2944-2956.

Hayden, J.A., Brophy, M.B., Cunden, L.S., and Nolan, E.M. (2013). High-affinity manganese coordination by human calprotectin is calcium-dependent and requires the histidine-rich site formed at the dimer interface. J Am Chem Soc 135, 775-787.

Heizmann, C.W., and Cox, J.A. (1998). New perspectives on S100 proteins: a multi-functional $\mathrm{Ca}^{2+}-, \mathrm{Zn}^{2+}$ - and $\mathrm{Cu}^{2+}$-binding protein family. Biometals 11, 383-397.

Heizmann, C.W., Fritz, G., and Schäfer, B.W. (2002). S100 proteins: structure, functions and pathology. Front Biosci 7, d1356-1368.

Hood, M.I., Mortensen, B.L., Moore, J.L., Zhang, Y., Kehl-Fie, T.E., Sugitani, N., Chazin, W.J., Caprioli, R.M., and Skaar, E.P. (2012). Identification of an Acinetobacter baumannii zinc acquisition system that facilitates resistance to calprotectin-mediated zinc sequestration. PLoS Pathog 8, e1003068.

Ikura, M. (1996). Calcium binding and conformational response in EF-hand proteins. Trends Biochem Sci 21, 14-17.

Kehl-Fie, T.E., Chitayat, S., Hood, M.I., Damo, S., Restrepo, N., Garcia, C., Munro, K.A., Chazin, W.J., and Skaar, E.P. (2011). Nutrient metal sequestration by calprotectin inhibits bacterial superoxide defense, enhancing neutrophil killing of Staphylococcus aureus. Cell Host Microbe 10, 158-164.

Kehl-Fie, T.E., Zhang, Y., Moore, J.L., Farrand, A.J., Hood, M.I., Rathi, S., Chazin, W.J., Caprioli, R.M., and Skaar, E.P. (2013). MntABC and MntH contribute to systemic Staphylococcus aureus infection by competing with calprotectin for nutrient manganese. Infect Immun 81, 3395-3405.

Kizawa, K., Jinbo, Y., Inoue, T., Takahara, H., Unno, M., Heizmann, C.W., and Izumi, Y. (2013a). Human S100A3 tetramerization propagates $\mathrm{Ca}^{2+} / \mathrm{Zn}^{2+}$ binding states. Biochim Biophys Acta 1833, 1712-1719.

Kizawa, K., Unno, M., Takahara, H., and Heizmann, C.W. (2013b). Purification and characterization of the human cysteine-rich S100A3 protein and its pseudo citrullinated forms expressed in insect cells. Methods Mol Biol 963, 73-86.

Koch, M., Bhattacharya, S., Kehl, T., Gimona, M., Vasak, M., Chazin, W., Heizmann, C.W., Kroneck, P.M., and Fritz, G. (2007). Implications on zinc binding to S100A2. Biochim Biophys Acta 1773, 457-470.

Kordowska, J., Stafford, W.F., and Wang, C.L. (1998). $\mathrm{Ca}^{2+}$ and $\mathrm{Zn}^{2+}$ bind to different sites and induce different conformational changes in human calcyclin. Euro J Biochem 253, 57-66.

Korndorfer, I.P., Brueckner, F., and Skerra, A. (2007). The crystal structure of the human (S100A8/S100A9)2 heterotetramer, calprotectin, illustrates how conformational changes of interacting alpha-helices can determine specific association of two EF-hand proteins. J Mol Biol 370, 887-898.

Leon, R., Murray, J.I., Cragg, G., Farnell, B., West, N.R., Pace, T.C., Watson, P.H., Bohne, C., Boulanger, M.J., and Hof, F. (2009). Identification and characterization of binding sites on S100A7, a participant in cancer and inflammation pathways. Biochemistry 48, 10591-10600.

Lin, J., Yang, Q., Yan, Z., Markowitz, J., Wilder, P.T., Carrier, F., and Weber, D.J. (2004). Inhibiting S100B restores p53 levels in primary malignant melanoma cancer cells. J Biol Chem 279, 34071-34077.

Linse, S., and Chazin, W.J. (1995). Quantitative measurements of the cooperativity in an EF-hand protein with sequential calcium binding. Protein Sci 4, 1038-1044.

Malashkevich, V.N., Dulyaninova, N.G., Ramagopal, U.A., Liriano, M.A., Varney, K.M., Knight, D., Brenowitz, M., Weber, D.J., Almo, S.C., and Bresnick, A.R. (2010). Phenothiazines inhibit S100A4 function by inducing protein oligomerization. Proc Natl Acad Sci USA 107, 8605-8610.

Maler, L., Sastry, M., and Chazin, W.J. (2002). A structural basis for S100 protein specificity derived from comparative analysis of apo and $\mathrm{Ca}^{2+}$-calcyclin. J mol biol 317, 279-290.

Moore, B.W. (1965). A soluble protein characteristic of the nervous sys- tem. Biochem Biophys Res Commun 19, 739-744.

Moroz, O.V., Antson, A.A., Dodson, E.J., Burrell, H.J., Grist, S.J., Lloyd, R.M., Maitland, N.J., Dodson, G.G., Wilson, K.S., Lukanidin, E., and Bronstein, I.B. (2002). The structure of S100A12 in a hexameric form and its proposed role in receptor signalling. Acta Crystallogr D Biol Crystallogr 58, 407-413.

Moroz, O.V., Antson, A.A., Grist, S.J., Maitland, N.J., Dodson, G.G., Wilson, K.S., Lukanidin, E., and Bronstein, I.B. (2003). Structure of the human S100A12-copper complex: implications for host-parasite defence. Acta Crystallogr D Biol Crystallogr 59, 859-867.

Moroz, O.V., Blagova, E.V., Wilkinson, A.J., Wilson, K.S., and Bronstein, I.B. (2009a). The crystal structures of human S100A12 in apo form and in complex with zinc: new insights into S100A12 oligomerisation. J Mol Biol 391, 536-551.

Moroz, O.V., Burkitt, W., Wittkowski, H., He, W., Ianoul, A., Novitskaya, V., Xie, J., Polyakova, O., Lednev, I.K., Shekhtman, A., Derrick, P.J., Bjoerk, P., Foell, D., and Bronstein, I.B. (2009b). Both $\mathrm{Ca}^{2+}$ and $\mathrm{Zn}^{2+}$ are essential for S100A12 protein oligomerization and function. BMC Biochem 10, 11.

Moroz, O.V., Burkitt, W., Wittkowski, H., He, W., Ianoul, A., Novitskaya, V., Xie, J., Polyakova, O., Lednev, I.K., Shekhtman, A., Derrick, P.J., Bjoerk, P., Foell, D., and Bronstein, I.B. (2009). Both $\mathrm{Ca}^{2+}$ and $\mathrm{Zn}^{2+}$ are essential for s100a12 protein oligomerization and function. BMC Biochem $10,11$.

Moroz, O.V., Wilson, K.S., and Bronstein, I.B. (2011). The role of zinc in the S100 proteins: insights from the X-ray structures. Amino Acids 41, 761-772.

Murray, J.I., Tonkin, M.L., Whiting, A.L., Peng, F., Farnell, B., Cullen, J.T., Hof, F., and Boulanger, M.J. (2012). Structural characterization of S100A15 reveals a novel zinc coordination site among S100 proteins and altered surface chemistry with functional implications for receptor binding. BMC Struct Biol 12, 16.

Nakashige, T.G., Zhang, B., Krebs, C., and Nolan, E.M. (2015). Human calprotectin is an iron-sequestering host-defense protein. Nat Chem Biol 11, 765-771.

Nelson, M.R., and Chazin, W.J. (1998). Structures of EF-hand $\mathrm{Ca}^{2+}$-binding proteins: diversity in the organization, packing and response to $\mathrm{Ca}^{2+}$ binding. Biometals 11, 297-318.

Nelson, M.R., Thulin, E., Fagan, P.A., Forsen, S., and Chazin, W.J. (2002). The EF-hand domain: a globally cooperative structural unit. Protein Sci 11, 198-205.

Nishikawa, T., Lee, I.S., Shiraishi, N., Ishikawa, T., Ohta, Y., and Nishikimi, M. (1997). Identification of S100b protein as copper-binding protein and its suppression of copper-induced cell damage. J Biol Chem 272, 23037-23041.

Ostendorp, T., Diez, J., Heizmann, C.W., and Fritz, G. (2011). The crystal structures of human S100B in the zinc- and calcium-loaded state at three $\mathrm{pH}$ values reveal zinc ligand swapping. Biochim Biophys Acta 1813, 1083-1091.

Ostendorp, T., Leclerc, E., Galichet, A., Koch, M., Demling, N., Weigle, B., Heizmann, C.W., Kroneck, P.M., and Fritz, G. (2007). Structural and functional insights into RAGE activation by multimeric S100B. EMBO J 26, 3868-3878.

Pei, J., Kim, B.H., and Grishin, N.V. (2008). PROMALS3D: a tool for multiple protein sequence and structure alignments. Nucleic Acids Res 36, 2295-2300.

Potts, B.C., Carlstrom, G., Okazaki, K., Hidaka, H., and Chazin, W.J. (1996). 1H NMR assignments of apo calcyclin and comparative structural analysis with calbindin D9k and S100 beta. Protein Sci 5, 2162-2174.

Potts, B.C., Smith, J., Akke, M., Macke, T.J., Okazaki, K., Hidaka, H., Case, D.A., and Chazin, W.J. (1995). The structure of calcyclin reveals a novel homodimeric fold for $\mathrm{S} 100 \mathrm{Ca}^{2+}$-binding proteins. Nat Struct Biol 2, 790-796.

Rustandi, R.R., Baldisseri, D.M., Drohat, A.C., and Weber, D.J. (1998). The $\mathrm{Ca}^{2+}$-dependent interaction of $\mathrm{s} 100 \mathrm{~b}$ (beta beta) with a peptide derived from p53. Biochemistry 37, 1951-1960.

Schäfer, B.W., and Heizmann, C.W. (1996). The S100 family of EF-hand calcium-binding proteins: functions and pathology. Trends Biochem 
Sci 21, 134-140.

Schäfer, B.W., Fritschy, J.M., Murmann, P., Troxler, H., Durussel, I., Heizmann, C.W., and Cox, J.A. (2000). Brain S100A5 is a novel calcium-, zinc-, and copper ion-binding protein of the EF-hand superfamily. J Biol Chem 275, 30623-30630.

Schaub, M.C., and Heizmann, C.W. (2008). Calcium, troponin, calmodulin, S100 proteins: from myocardial basics to new therapeutic strategies. Biochem Biophys Res Commun 369, 247-264.

Sigel, A., and Sigel, H. (2000). Manganese and its role in biological processes (New York: Marcel Dekker).

Sivaraja, V., Kumar, T.K., Rajalingam, D., Graziani, I., Prudovsky, I., and Yu, C. (2006). Copper binding affinity of S100A13, a key component of the FGF-1 nonclassical copper-dependent release complex. Biophys J 91, 1832-1843.

Striz, I., and Trebichavsky, I. (2004). Calprotectin-a pleiotropic molecule in acute and chronic inflammation. Physiol Res 53, 245-253.

Sturchler, E., Cox, J.A., Durussel, I., Weibel, M., Heizmann, C.W. (2006). S100A16, a novel calcium-binding protein of the EF-hand superfamily. J Biol Chem 281, 38905-38917.

Unno, M., Kawasaki, T., Takahara, H., Heizmann, C.W., and Kizawa, K. (2011). Refined crystal structures of human $\mathrm{Ca}^{2+} / \mathrm{Zn}^{2+}$-binding S100A3 protein characterized by two disulfide bridges. J Mol Biol 408, 477-490.

van Dieck, J., Teufel, D.P., Jaulent, A.M., Fernandez-Fernandez, M.R., Rutherford, T.J., Wyslouch-Cieszynska, A., and Fersht, A.R. (2009). Posttranslational modifications affect the interaction of S100 proteins with tumor suppressor p53. J Mol Biol 394, 922-930.

Vogl, T., Leukert, N., Barczyk, K., Strupat, K., and Roth, J. (2006). Biophysical characterization of S100A8 and S100A9 in the absence and presence of bivalent cations. Biochim Biophys Acta 1763, 1298-1306.

Vorum, H., Madsen, P., Rasmussen, H.H., Etzerodt, M., Svendsen, I., Celis, J.E., and Honoré, B. (1996). Expression and divalent cation binding properties of the novel chemotactic inflammatory protein psoriasin. Electrophoresis 17, 1787-1796.

Wilder, P.T., Baldisseri, D.M., Udan, R., Vallely, K.M., and Weber, D.J. (2003). Location of the $\mathrm{Zn}^{2+}$-binding site on S100B as determined by NMR spectroscopy and site-directed mutagenesis. Biochemistry 42, 13410-13421.

Wilder, P.T., Varney, K.M., Weiss, M.B., Gitti, R.K., and Weber, D.J. (2005). Solution structure of zinc- and calcium-bound rat S100B as determined by nuclear magnetic resonance spectroscopy. Biochemistry $44,5690-5702$.

Wolf, R., Howard, O.M., Dong, H.F., Voscopoulos, C., Boeshans, K., Winston, J., Divi, R., Gunsior, M., Goldsmith, P., Ahvazi, B., Chavakis, T., Oppenheim, J.J., and Yuspa, S.H. (2008). Chemotactic activity of S100A7 (Psoriasin) is mediated by the receptor for advanced glycation end products and potentiates inflammation with highly homologous but functionally distinct S100A15. J Immunol 181, 1499-1506.

Zackular, J.P., Chazin, W.J., and Skaar, E.P. (2015). Nutritional immunity: S100 proteins at the host-pathogen interface. J Biol Chem 290, 18991-18998.

Open Access This article is distributed under the terms of the Creative Commons Attribution License which permits any use, distribution, and reproduction in any medium, provided the original author(s) and source are credited. 